\title{
THE EFFECT OF SALES SMOOTHING ON INVENTORY PERFORMANCE
}

\section{WPLYW POPRAWY PLYNNOŚCI SPRZEDAŻY NA EFEKTYWNOŚĆ GOSPODARKI MAGAZYNOWEJ}

\author{
Anthony S. White, Raj Gill, Michael Censlive \\ School of Engineering and Information Sciences, \\ Middlesex University, the Burroughs, Hendon, London NW4 4BT, United Kingdom \\ Phone +442084115212, Fax +44208411, Email a.white@mdx.ac.uk
}

\begin{abstract}
This paper outlines $\mathrm{z}$ transform methods used to describe control of an inventory system. It examines how the form of the sales smoothing function affects the performance and sensitivity of the system to smoothing transfer functions. Graphical output from the Simulink package used the equations developed for an AIOBPCS inventory system.

The analysis using sensitivity functions illustrates the frequency range over which the system is sensitive to the sales smoothing. For practical exponential smoothing this sensitive frequency window is in the range of weekly variations. The results presented here illustrate that the control-theoretic models show how sensitive the inventory is to sales smoothing. Replacing the traditional moving average technique with one based on control theory results in much lower stockout.
\end{abstract}

Keywords: Vendor-Managed-Inventory, discrete-simulation, sales smoothing, sensitivity.

Streszczenie: W niniejszym artykule opisano metody używane do kontroli systemu gospodarki magazynowej, a także zbadano, w jaki sposób kształtowanie funkcji poprawy płynności sprzedaży (sales smoothing) wpływa na efektywność, a także jaka jest wrażliwość systemu na funkcje poprawy płynności przesyłu. Graficzne wyniki, uzyskane z pakietu oprogramowania Simulink, otrzymano przy zastosowaniu równań opracowanych dla systemu gospodarki magazynowej AIOBPCS.

Analiza z wykorzystaniem funkcji wrażliwości przedstawia zakres częstotliwości, dla których system jest wrażliwy na poprawę płynności sprzedaży. Dla praktycznej wykładniczej poprawy płynności to okno „wrażliwych” częstotliwości mieści się w zakresie wahań tygodniowych. Przedstawione tutaj wyniki ilustrują tezę, iż teoretyczne modele sterowania pokazują jak wrażliwa jest gospodarka magazynowa na płynność sprzedaży. Zastapienie tradycyjnych technik, opartych na uśrednionych wartościach przemieszczeń, technikami bazującymi na teorii sterowania skutkuje znaczącym obniżeniem koniecznych zapasów magazynowych.

Słowa kluczowe: zarządzanie zapasami przez dostawcę (VMI), symulacja dyskretna, poprawa płynności sprzedaży, wrażliwość 


\section{Introduction}

The problems of production and inventory have posed significant problems throughout the history of manufactured goods. Many different analytical techniques have been used with no one technique being wholly adequate in providing all the necessary solutions. However the consideration of the information flows, the effects of batch sizes and scheduling has now reached a position where the economic penalties of excess stock and the poor western practices were thrown into sharp relief by the Toyota lean production regime. New e-manufacturing environments are concerned with rapid response (Gordon 2002) and are generally concerned with Factory-to-Business (F2B) initiatives with the use of Lean and Agile manufacturing processes driving manufacturing engineers to look for greater efficiency in the Supply Chain. Disney \& Towill (2002a) at Cardiff University and White \& Censlive (2006) have analysed Supply Chains with Automatic Pipeline, Inventory and Order Based Production Control Systems APIOBPCS) (figure 1) extensively, to determine its' stability and optimisation (Disney \& Towill 2002b). The actual inventory at the distributor is compared with the agreed re-order point. This decision is arrived at by consideration of Customer Service Levels (CSL) whilst not building up excessive stocks. The agreed procedure embedded in the APIOBPCS was found by Riddalls and Bennett (2002) to follow human behaviour as observed by Sterman (1989) from executives the playing of the 'Beer Game'.

In this APIOBPCS model of a factory and sales system we see that the distributor produces virtual sales orders assuming a typical pattern of behaviour. These orders are further modified by the factory using experience of the learning curve over time (An effective exponential delay). This is added to a fraction of the inventory error, plus a fraction of the Work In Progress (WIP) error. This comprises the order rate, which then will after a delay, lead to production being completed. From this completion rate the virtual sales rate is subtracted and the accumulation of these products leads to the inventory.

The purpose of this paper is to examine the effect of the sales smoothing function on the overall inventory response.

\section{Inventory Models}

Simon (1952) originally proposed the use of transform techniques to inventory and order based production systems. Tustin (1953) and Vassian (1954) also applied transform techniques to economic and inventory systems in the 1950's. Later in the 1960's Forrester (1961) applied the methods of Industrial Dynamics simulation to the problem. Forrester devised the method of System Dynamics to describe 
problems that were not amenable by other means, primarily those, which included human decisions. The principle arguments were that ALL such processes could be described in simple forms by the feedback loops inherent in the information flows and the delays represented in those flows. Since he recognised the inherent nonlinearity of all the processes being described he was only able to use a basic continuous simulation package to obtain numerical results. He used exponential transfer functions to represent the delays, as he believed that they represented physical reality better for the majority of real situations.

Figure 1 illustrates the control-theoretic model of the AIOBPCS.

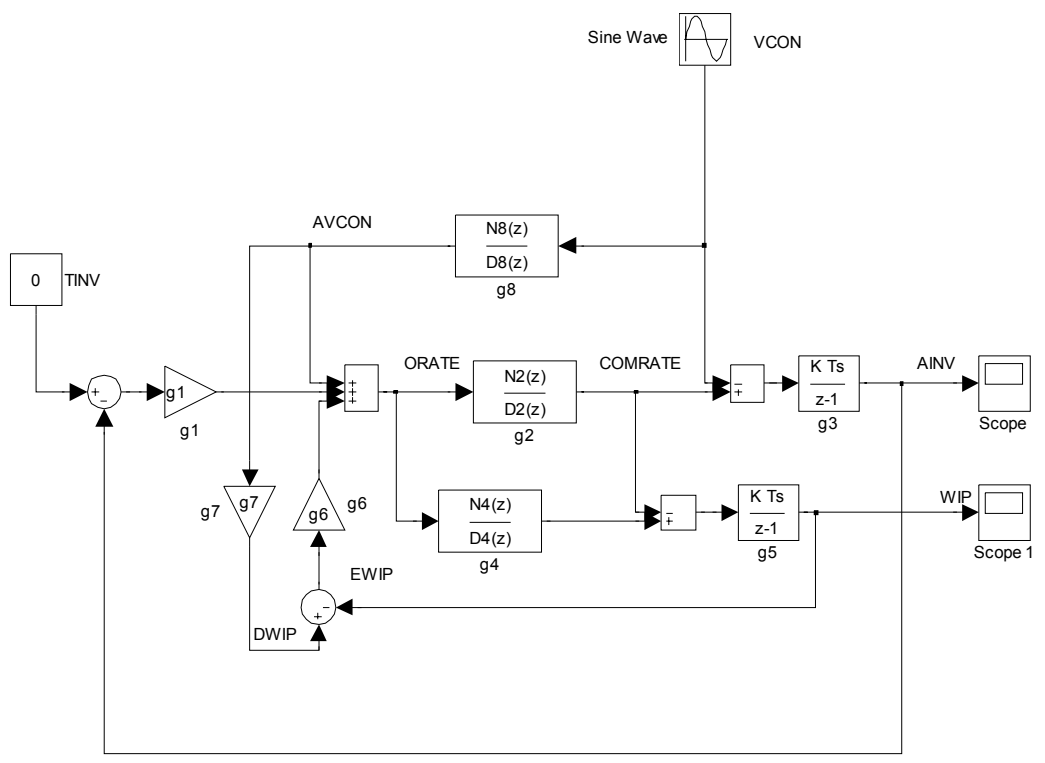

Fig. 1 APIOBPCS model

In the late 1960's Adelson (1966) had used z transforms in an inventory and orderbased system, producing an analytical expression for bullwhip. More recent work using analytical methods by Towill's group at Cardiff University is the origin of the work here. Towill and his students modelled the operations at a biomedical equipment factory, Biomet Ltd. Although no validation data has been published the APIOBPCS model was derived from the procedures adopted by Biomet. Since the performance of Biomet inventory and stock levels improved considerably, it must at least be a satisfactory model. 


\subsection{Types of models available}

The criticism of Riddalls et al of Forrester's simulation methods is that they do not give general design principles for managers. Towill's control-theoretic models do allow an analytical approach to the problem, while retaining the dynamics of the situation, unlike traditional operational research (OR) methods described by statistical or quasi-static methods (Lewis 1981). Ferris and Towill (1993) made a systematic investigation of the effects of various feedback and feed-forward options for inventory control. Towill and Del Vecchio (1994) examined a supply chain using the IOPBCS model. They devised a filter system approach to reduce the 'Bullwhip' phenomenon. Current work by this team is aligned with the performance of the APIOBPCS model. The disadvantage of the System Dynamics models with extensive non-linearity is that few or any general analytical predictions can be made. Transform models that are linear correspond to observed industrial practice and do match measurements of managerial behaviour made by Sterman (1989). In principle they capture the main features of the systems while allowing a greater level of analysis. It is correct that these models are linear and represent a lumped view of the delays present in the organisation. These problems can also be represented as state-space equations, either as continuous or discrete models.

\subsection{The System Models}

In the early descriptions of System Dynamics, delays were assumed to be exponential in form, in control terms-an exponential lag. Hence the delays due to production for example are described by a simple time constant $T_{p}$. This is typically the modelling process used in System Dynamics software such as Stella or Vensim. In the transform models used here the differential equations can be modelled using Laplace transforms if we assume that a large number items are being handled or for a smaller set of objects, that are better described by difference equations, which can then be modelled using $\mathrm{z}$ transforms. Both these techniques are limited to linear models but have great power in allowing general expressions for the response to be obtained.

The key to the way the inventory system behaves is the rate of ordering. The main structural system that has been investigated here is that of the Automatic Pipeline, Inventory and Order Based Production Control System (APIOBPCS) (Disney and Towill 2002a). The inventory error (EINV) is found as the difference between a fixed desired level of inventory (TINV) and the actual inventory (AINV). A smoothing function is used to obtain the average sales consumption (AVCON) as a function of the virtual consumption rate VCON. In his earlier work, Towill (1972) showed that the averaging techniques used in industry could be modelled by an exponential lag in a continuous model. This value is then used to obtain the 
The Effect of Sales Smoothing on Inventory Performance

Wptyw poprawy ptynności sprzedaży na efektywność gospodarki magazynowej

order rate (ORATE) given to the production facility, wherever it is. There is generally a production delay inherent in the manufacturing process.

The Order rate (ORATE) is obtained from the sum of a fraction of the exponentially smoothed virtual sales plus a fraction of the error in inventory plus a fraction of the perceived error in Work In Progress. Payment is often requested at this point. It does not matter who is in actual control of the network as far as the model is concerned.

These pipeline and inventory loop gains are critical parameters concerned with the stability of the whole system.

Disney and colleagues represent this production delay as a pure discrete delay $\mathrm{z}^{-T p}$. The value of production delay is crucial to the behaviour of the system since for increasing values of this delay will eventually lead to system instability.

\section{Sensitivity Analysis}

Sensitivity analysis in control engineering is performed to understand how parameters cause the system to behave and is defined (Franklin \& Powell 1994) as:

$$
\mathrm{S}_{\mathrm{x}}=\frac{\mathrm{x}}{\mathrm{M}} \frac{\partial \mathrm{M}}{\partial \mathrm{x}}
$$

The overall transfer function of figure 1 is:

$$
M=\frac{g_{3}\left(g_{2} g_{8}\left(1+g_{6} g_{7}\right)-1-g_{5} g_{6}\left(g_{4}-g_{2}\right)\right)}{\left(1+g_{1} g_{2} g_{3}+g_{5} g_{6}\left(g_{4}-g_{2}\right)\right)}
$$

The sensitivity $\mathrm{S}_{8}$ to the sales smoothing function $\mathrm{g}_{8}$, is given by:

$$
\mathrm{S}_{8}=\frac{\mathrm{g}_{8} \mathrm{~g}_{2}\left(1+\mathrm{g}_{6} \mathrm{~g}_{7}\right)}{\left(\mathrm{g}_{2} \mathrm{~g}_{8}\left(1+\mathrm{g}_{6} \mathrm{~g}_{7}\right)-1-\mathrm{g}_{5} \mathrm{~g}_{6}\left(\mathrm{~g}_{4}-\mathrm{g}_{2}\right)\right)}
$$

As an example the local transfer functions are:

$\mathrm{g}_{1}=\frac{1}{\mathrm{~T}_{\mathrm{i}}} ; \mathrm{g}_{2}=\mathrm{z}^{-\mathrm{T}_{\mathrm{p}}-1} ; \mathrm{g}_{3}=\frac{\mathrm{z}}{\mathrm{z}-1} ; \mathrm{g}_{4}=\frac{1}{\mathrm{z}} ; \mathrm{g}_{5}=\frac{\mathrm{z}}{\mathrm{z}-1} ; \mathrm{g}_{6}=\frac{1}{\mathrm{~T}_{\mathrm{w}}} ; \mathrm{g}_{7}=\mathrm{T}_{\overline{\mathrm{p}}} ; \mathrm{g}_{8}=\frac{\mathrm{z}}{\left(\left(\mathrm{T}_{\mathrm{a}}+1\right) \mathrm{z}-\mathrm{T}_{\mathrm{a}}\right)}$

To give an illustrative example the values commonly used by Towill are $\mathrm{T}_{\mathrm{a}}=4,8 ; \mathrm{T}_{\mathrm{i}}=2 ; \mathrm{T}_{\mathrm{w}}=2 ; \mathrm{T}_{\mathrm{p}}=4$. 
The Bode frequency plots are shown in figure 2 for the sensitivities $S_{1}, S_{2}$ as well as $\mathrm{S}_{8}$. Sensitivity to the inventory error gain $\mathrm{g}_{1}$, shown in the top Bode diagram, illustrates the problem as weekly changes are experienced. The overall response is sensitive to changes in $g_{1}$ at this frequency. The middle Bode diagram in figure 2 shows the effects of frequency variations of the virtual consumption on the sensitivity to the sales smoothing transfer function. The high gain at low frequencies means that long term variations will be unduly emphasised by this type of smoothing. What is more challenging are the two peaks at 1.16 and $2.5 \mathrm{rad} /$ day. These show a worrying sensitivity to weekly variations, typically for $T_{a}=4$ or 8 weeks. Often companies will update their information on a weekly basis. Knowledge of the precise value of production delay will cause exceptional effects as shown in the lower diagram of figure 2 . This is highly important for variations at very low frequencies, say on monthly cycles.

What can we do to overcome this sensitivity? The possibility exists to choose a different sales filter, which would give a better overall transfer function with better control of the inventory. One possibility is the use of a lead lag filter represented by:

$$
\mathrm{g}_{8 \mathrm{mod}}=\frac{0.8443(\mathrm{z}-0.7168)}{(\mathrm{z}-0.6052)}
$$

The use of this filter to average the sales figures would give a much better inventory control as shown in figure 3 with reduced stockout.

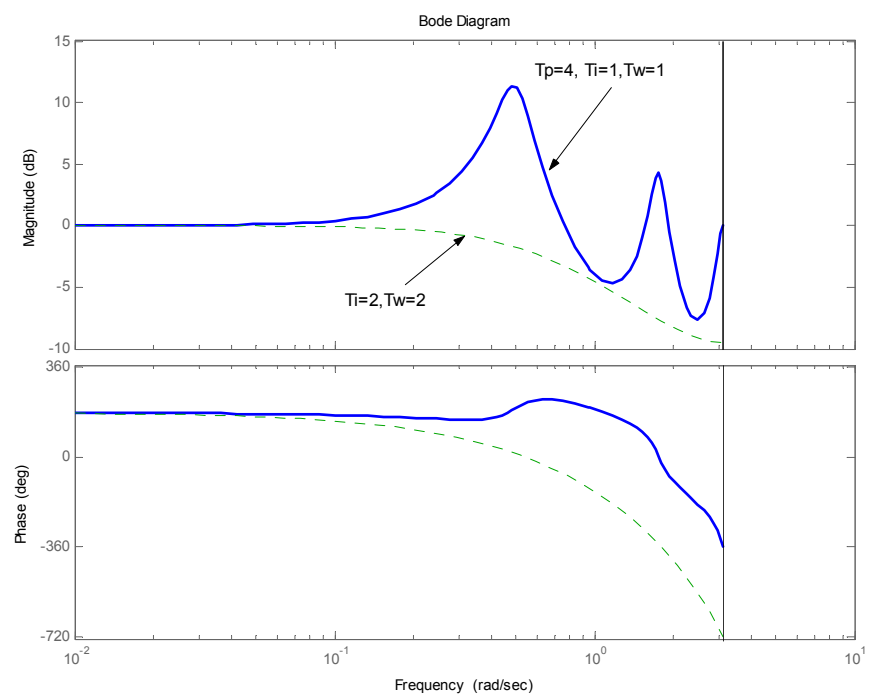

Fig. 2a Sensitivity function $\mathrm{S}_{1}$ 
The Effect of Sales Smoothing on Inventory Performance
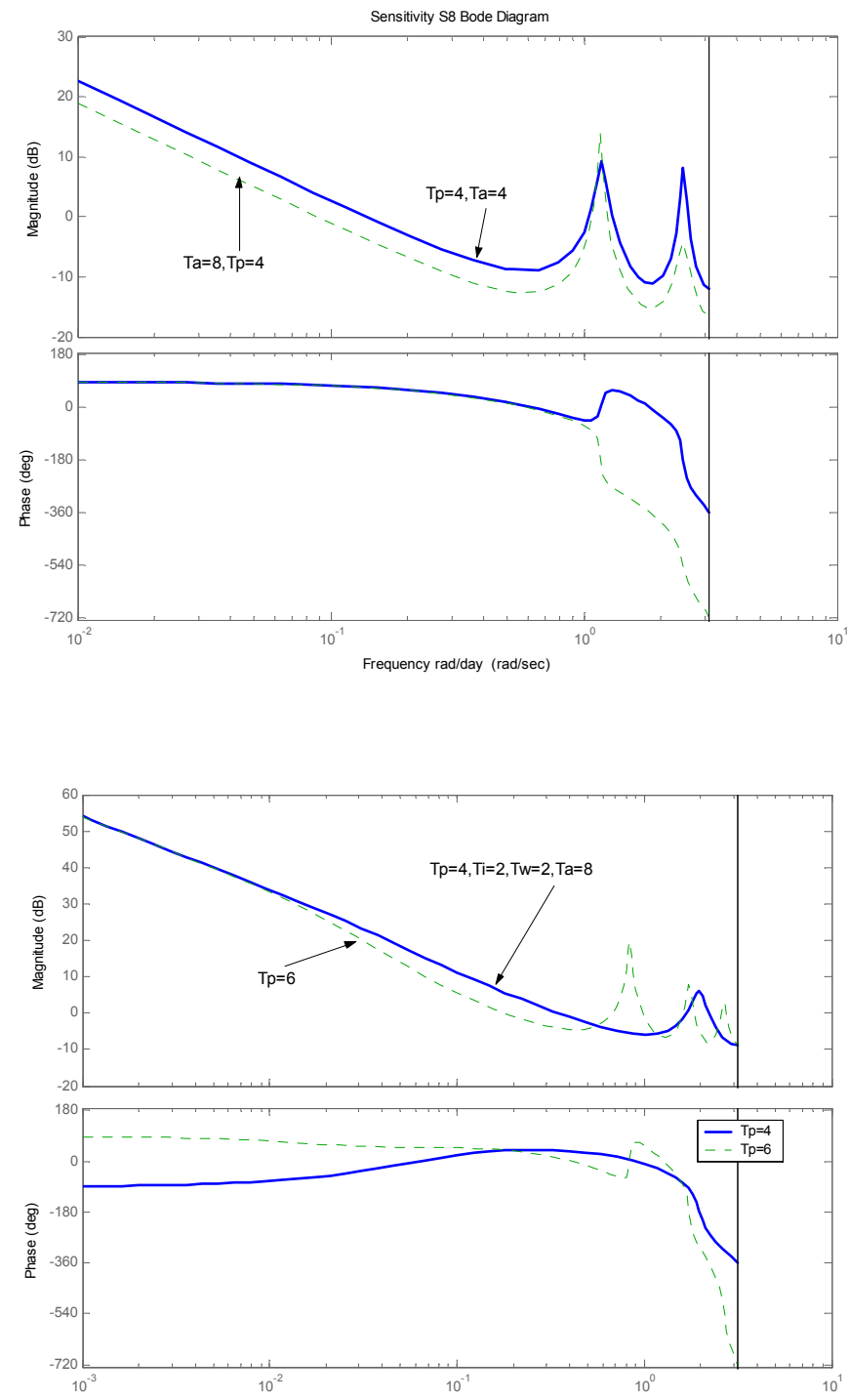

Fig. 2b\&c Sensitivity functions $S_{2} \& S_{8}$ 


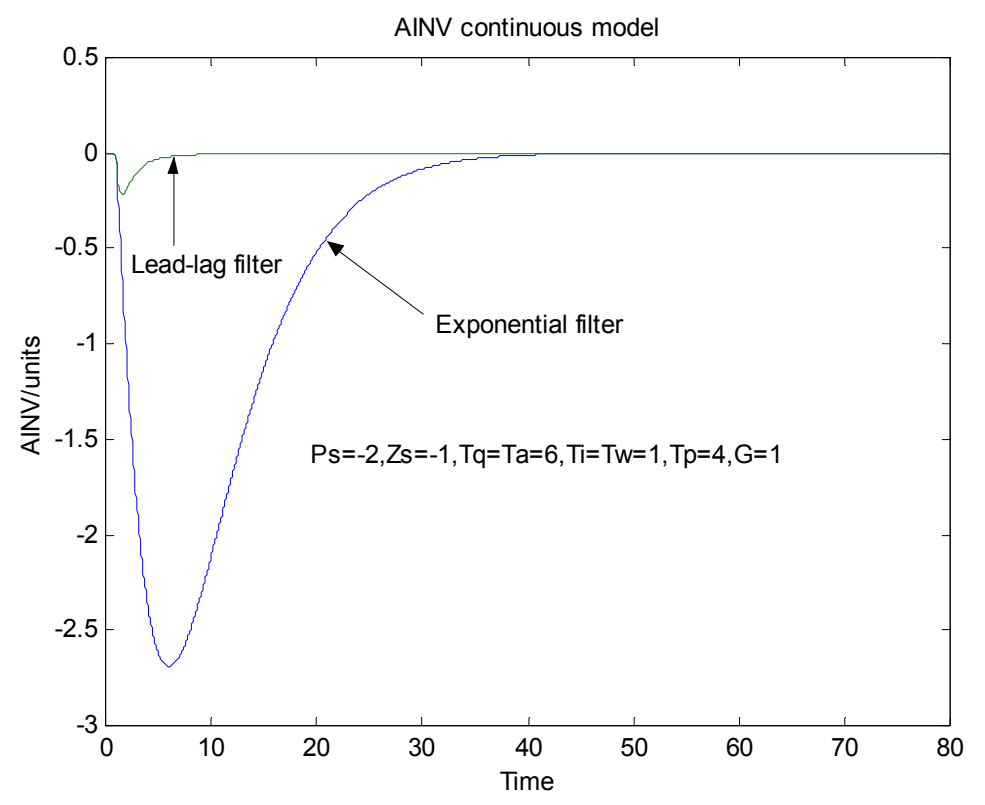

Fig. 3 Inventory performance with lead-lag filter to smooth sales step input

Figure 3 shows the inventory level when subjected to a step sales input for the conventional sales filter and a modified filter given by $\mathrm{g}_{8}$. It is clear that the new filter design exhibits considerable improvement. Since the $\mathrm{Z}$ transformed variables can be written in terms of finite difference equations it would be easy to implement these on a spreadsheet.

\section{Conclusions}

- The APIOBPCS inventory system is widely used and has a useful discrete control model as illustrated here. The model has been used to predict inventory performance and stability boundaries.

- The sensitivity to inventory error gain changes is important in weekly and sub weekly variations of sales

- The sensitivity to knowledge of production delays is important for slow changes in sales

- The sensitivity of the smoothing transfer function has been evaluated and shown to indicate a high gain at very low frequencies and at frequencies around one weekly cycle.

- This can be reduced by using a different filter function which allows a much better inventory performance.

- This could be implemented using a spreadsheet. 
The Effect of Sales Smoothing on Inventory Performance

209

Wplyw poprawy plynności sprzedaży na efektywność gospodarki magazynowej

\section{References}

1. Gordon, L. F., "The e-skip-gen effect. The emergence of a cybernetic management model and the F2B market segment for industry", Int. J. Production Economics, Vol. 80, pp.11-29. 2002.

2. Disney, S.M., Towill, D.R. "A discrete transfer function model to determine the dynamic stability of a vendor managed inventory supply chain", Int. J. Prod. Res., Vol. 40, No1, pp.179-204. 2002a.

3. White, A.S. \& Censlive, M, 'Observations on modeling strategies for vendor managed inventory', J. Manufacturing Technology Management, Vol 17, No. 4, pp 496-512. 2006

4. Disney, S.M., Towill, D.R. "A procedure for the optimisation of the dynamic response of a vendor managed inventory system", Computers \& Industrial Engineering, Vol. 43, pp.27-58. 2002b

5. Riddalls, C.E., Bennett, S. "Production-inventory system controller design and supply chain dynamics", Int. J. of Systems Science, Vol. 33, No3, pp.181-195. 2002

6. Sterman J.D. "Modelling managerial behaviour: Misperceptions of feedback in a dynamic decision making experiment", Management Science, Vol.35, No3, pp.321-339. 1989.

7. Simon, H.A. "On the application of servomechanism theory to the study of production control", Econometra, Vol. 20, pp.247-268. 1952.

8. Tustin, A. "The mechanism of Economic Systems", Heinemann, London. 1953

9. Vassian, H.J. "Application of discrete variable servo theory to inventory control", J.. of the Operations research Society of America, Vol.3, No 3, pp.272-282. 1954

10. Forrester, J. Industrial Dynamics, MIT press, Boston, 1961.

11. Adelson, R.M., "The dynamic behaviour of linear forecasting and scheduling rules", Operational research Quarterly, Vol. 17, No 4, pp.447-462. 1966

12. Lewis, C. D, "Scientific Inventory Control", Butterworth, London. 1981

13. Ferris, J., Towill, D.R, "Benchmarking a Generic Family of Dynamic Manufacturing Ordering and Control Models" J. Syst. Eng., Vol. 3, pp.170182. 1993

14. Towill, D.R., Del Vecchio, A. "The application of filter theory to the study of supply chain dynamics", Prod. Planning \& Control, Vol. 5, No1, pp.82-96. 1994

15. Towill, D.R. "Exponential smoothing of learning curve data", Int. J. Prod. Res., Vol.15, No.1, pp.1-15. 1972

16. Franklin, G.F, Powell, J.D, Emami-Naeini, A "Feedback Control of Dynamic Systems", 3rd ed., Addison-Wesley, Massachusetts, pp422, 1994. 


\section{Symbols}

$\begin{array}{ll}\text { AINV } & \text { Current Inventory level } \\ \text { AVCON } & \text { Average sales rate } \\ \text { CONS } & \text { Sales consumption or market demand } \\ \text { COMRATE } & \text { Rate of production } \\ \text { CSL } & \text { Customer service levels } \\ \text { EINV } & \text { Error in inventory level } \\ \text { EPOS } & \text { Electronic point of sale } \\ \text { EWIP } & \text { Error in WIP } \\ \text { g }_{1} \text { etc } & \text { Transfer functions } \\ \text { DINV } & \text { Distributor inventory } \\ \text { M } & \text { System transfer function } \\ \text { ORATE } & \text { Outstanding level of orders placed with the supplier } \\ \text { TINV } & \text { Target inventory } \\ T_{a} T_{q} & \text { Smoothing time constants } \\ T_{i} & \text { Inventory order constant time. } \\ T_{w} & \text { WIP order constant time. } \\ T_{P} & \text { Production delay time } \\ T_{P b a r} & \text { multiplier from smoothed sales to WIP demand } \\ \text { APIOBPCS } & \text { Automatic Pipeline Inventory and Order Based Production Control } \\ & \text { System } \\ \text { VCON } & \text { virtual consumption } \\ \text { WIP } & \text { Work In Progress } \\ \mathrm{x} & \text { variable } \\ \mathrm{z} & \mathrm{z} \text { transform }\end{array}$

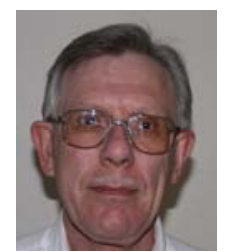

Anthony S White, Professor of Systems Engineering in the School of Engineering and Information Sciences Middlesex University is the former Dean of the School of Engineering Systems at Middlesex University. He worked for Hawker Siddeley Dynamics, Roll Royce and has extensive consultancy for SME's. With Professor Raj Gill he has implemented JIT and SPC systems in local companies. Current research interests include supply chain dynamics, software project management and complex human systems. He was trained at Queen Mary College as an Aeronautical engineer and worked on guided weapons and aeroelasticity in particular. Professor White has obtained and worked on projects from the EU, Industry and research bodies as well as publishing over 150 papers.

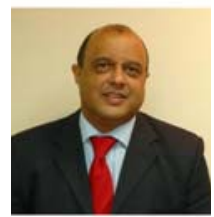

Dr Raj Gill, staff of the Middlesex University, London, ISPE President, researcher in manufacturing engineering, educator, coordinator of several international projects both in $\mathrm{R} \& \mathrm{D}$ and engineering education.

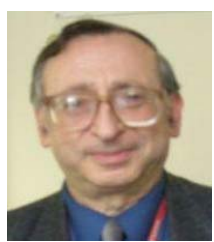

Dr Michael Censlive graduated from Imperial College with a $\mathrm{PhD}$ in Physics. He worked for several companies implementing novel manufacturing techniques and was responsible for the quality procedures at Texas Instruments in Bedford. He has considerable experience as a production manager for electronic devices. 